\title{
PENGOLAHAN AIR PAYAU MENGGUNAKAN TEKNOLOGI MEMBRAN SISTEM OSMOSA BALIK \\ SEBAGAI ALTERNATIF PEMENUHAN KEBUTUHAN AIR MINUM MASYARAKAT KEPULAUAN SERIBU
}

\author{
Oleh : \\ Wahyu Widayat \\ Kelompok Teknologi Pengelolaan Air bersih dan Limbah Cair, Pusat Pengkajian dan Penerapan \\ Teknologi Lingkungan, BPPT.
}

\begin{abstract}
Kepulauan seribu (Seribu Archipelago) is one of region of north jakarta, the province of DKI Jakarta Raya which is populated by around 18.000 inhabitants. It consists of 111 small islands. Among them, there are about 11 (eleven) islands are stated as the residential: P. Untung Jawa, P. Tidung Besar, P. Lancang Besar, P. Panggang, P. Pramuka, P. Kelapa I, P. Kelapa II, P. Harapan, P. Sebira. P. Payung dan P. Pari. P. Panggang and $P$. Kelapa I are the most populated.In relation to the clean water supply, specifically for drinking water/freshwater, mostly is got from the narrow well, rainfall and some water treatment installations that heve been owned by some islands. However, problem arises when the prolong dry season comes as the quality of water in the narrow well decreases significantly, the well water became brackish. In order to cope this problem, the avaibility of sufficient water treatment installations to process brackish water into freshwater is very important. The water treatment installation with reverse osmosis system is one of the most effective alternative in order to provide the freshwater for the people in the islands. The system has also been aplied sufficiently in several islands, such as P. Kelapa I, P. Tidung, P. Pramuka, P. Untung Jawa, P. Panggang dan P. Harapan
\end{abstract}

Kata Kunci : Pengolahan Air payau, Osmosa balik, Air minum.

\section{PENDAHULUAN}

Kepulauan seribu merupakan salah satu wilayah Jakarta Utara, Propinsi DKI Jakarta Raya dengan jumlah penduduk sekitar 18.000 jiwa. Kepulauan seribu terdiri dari 111 buah pulaupulau kecil. Pulau yang diperuntukkan sebagai daerah pemukiman ada sebelas buah pulau, yaitu: P. Untung Jawa, P. Tidung Besar, P. Lancang Besar, P. Panggang, P. Pramuka, P. Kelapa I, P. Kelapa II, P. Harapan, P. Sebira. P. Payung dan P. Pari. P. Panggang dan P. Kelapa I berpenduduk cukup padat.

Untuk memenuhi kebutuhan air bersih, terutama air untuk minum diperoleh dari sumur air tanah dangkal, air hujan dan air hasil pengolahan untuk beberapa pulau yang sudah mempunyai instalasi pengolahan air (IPA). Berdasarkan hasil penelitian Bappedalda, kualitas air tanah dangkal di beberapa lokasi sudah tercemar, sehingga tidak memenuhi syarat lagi untuk digunakan sebagai air minum. Air tanah dangkal yang saat ini dimanfaatkan oleh masyarakat setempat hanya tersedia pada saat musim hujan dan pada saat kemarau panjang air tawar akan habis, penampungan air hujan atau yang disebut PAH yang dimiliki oleh masyarakat kuantitasnya sangat terbatas, sehingga masyarakat kepulauan seribu mendatangkan dari daerah lain, seperti Tanjung Priok, Tangerang dan pulau-pulau lain yang masih ada sumber air tawar.

Dalam kondisi kemarau panjang kualitas air tanah dangkal menurun, akibat intrusi air laut, sehingga air menjadi payau bahkan asin karena tingginya kadar garam. Pada kondisi semacam itu kadar garam (Total Disssolved Solid mencapai 7.000 bahkan lebih). Dalam kondisi semacam ini sangat diperlukan instalasi pengolahan air (IPA) untuk mengolah air payau menjadi air tawar. Alternatif yang paling efektif yang adalah pembangunan unit Instalasi Pengolahan Air yang sesuai dengan kondisi air baku. Berdasarkan data kualitas air baku, proses yang harus diterapkan meliputi oksidasi, filtrasi dan desalinasi dengan sistem Osmosa Balik (Reverse Osmosis).

Instalasi Pengolahan Air dengan sistem reverse osmosis dirancang sesuai dengan tingkat sosial ekonomi serta kebutuhan air minum masyarakat setempat. Instalasi Pengolahan Air Payau dengan sistem osmosa balik tersebut merupakan rangkaian proses yang lengkap, namun dikemas dalam bentuk yang kompak dan 
sederhana sehingga masyarakat setempat mampu mengoperasikan unit pengolahan air ini dan dapat mengembangkan untuk lokasi -lokasi lain yang mempunyai kualitas sumber air baku sama. Beberapa pulau telah memiliki instalasi pengolahan air payau menggunakan teknologi membran (Reverse Osmosis atau Osmosa Balik), yaitu P. Kelapa I, P. Tidung, P. Pramuka, P. Untung Jawa, P. Panggang dan P. Harapan.

\section{PERMASALAHAN}

Kualitas air tanah dangkal di beberapa lokasi di kepulauan seribu sudah tercemar, sehingga tidak memenuhi syarat lagi untuk digunakan sebagai air minum. Ketersediaan air tanah dangkal rata-rata hanya tersedia pada saat musim penghujan dan pada musim kemarau panjang air tawar tanah dangkal menipis dan tidak mampu lagi memenuhi kebutuhan air tawar, sedangkan penampungan air hujan (PAH) kuantitasnya sangat terbatas, sehingga masyarakat kepulauan seribu untuk memenuhi kebutuhan air minum mendatangkan dari daerah lain, seperti Tanjung PriOk, Tangerang dan pulaupulau lain yang masih ada sumber air tawar dengan harga yang relatif mahal.

Seiring dengan pertambahan penduduk di kepulauan seribu ditambah lagi dengan musim kemarau panjang kualitas air tanah dangkal menurun, disebabkan oleh intrusi air laut, dimana air menjadi payau bahkan asin karena tingginya kadar garam, sehingga Dalam kondisi semacam ini sangat diperlukan instalasi pengolahan air yang mampu mengolah air payau menjadi air tawar.

\section{TUJUAN}

Dalam tulisan ini diuraikan salah satu cara mengatasi masalah air bersih (minum) di Kepulauan seribu dengan menerapkan teknologi pengolahan air payau dengan sistem osmosa balik

\section{METODOLOGI}

\subsection{Survei Lokasi}

Kegiatan survei ini dilakukan setelah datadata kependudukan (jumlah warga dan penyebarannya), data lokasi seperti luas daratan, data cuaca seperti curah hujan, data kualitas air yang akan diolah. Survai lapangan dilakukan untuk mengetahui kualitas air tanah, jumlah penduduk yang akan dilayani, kondisi sosial \& ekonomi masyarakatnya.

\subsection{Sampling Air}

Pengambilan sampel air dilakukan pada beberapa titik untuk mendapatkan data kualitas air yang dapat mewakili kualitas aderah sampling

\subsection{Penentuan Lokasi}

Penentuan lokasi Instalasi Pengolahan Air dengan teknologi membran sistem Osmosa Balik ini ditentukan dengan pertimbangan segi teknis pembangunan, pengoperasian dan distribusi. Sedapat mungkin ditempatkan pada jarak terdekat antara IPA dengan pemukiman dan sumber air yang akan diolah

\subsection{Ketersediaan bahan dan Peralatan}

Bahan dan peralatan yang diperlukan untuk membangun IPA dipilih dengan pertimbangan kemudahan dan ketersediaannya di pasaran, dengan tujuan mempermudah dan murah dalam kontruksi maupun operasionalnya.

\subsection{Disain Konstruksi}

Data kualitas air baku sangat penting dalam pengambilan keputusan proses yang akan digunakan, yaitu sebagai acuan penentuan jumlah bahan-bahan kimia yang digunakan dalam proses pengolahan air, sistem pengolahan pendahuluan yang akan digunakan, seperti oksidasi, dan filtrasi. Proses pengolahan lanjutan untuk air payau setelah pretreatment ialah proses desalinasi dengan penerapan teknologi membran sistem osmosa balik.

\subsection{Pembangunan Prototipe \& Pengujian}

Pembangunan Instalasi Pengolahan Air dengan teknologi membran sistem reverse osmosis di beberapa pulau di kepulauan seribu diawali dengan pembangunan bangunan pelindung peralatan, kemudian pemasangan pembangkit listrik dan konstruksi unit proses dalam Sistem IPA. Setelah seluruh pekerjaan pemasangan alat dilaksanakan, dilanjutkan pengujian karakteristik alat .

\subsection{Pelatihan Sumberdaya Manusia}

Masyarakat setempat diharapkan dapat mengelola IPA dengan teknologi membran sistem osmosa balik tersebut, yaitu mampu mengoperasikan, merawat peralatan dan menggulirkan hasil pengelolaan IPA. Untuk itu sebelum diserahkan kepada masyarakat untuk dikelola, dilakukan pelatihan pengoperasian dan perawatan Instalasi Pengolahan Air tersebut. 


\section{DESALINASI}

Proses pemisahan air tawar dari air asin disebut Desalinasi. Ada beberapa cara pengolahan air berdasarkan kadar salinitas, yaitu; distilasi, pembekuan, membran, penguapan dan penukar ion (Gambar 1). Teknologi proses desalinasi yang telah banyak dipakai antara lain, yakni proses distilasi yang berdasarkan penguapan, proses filtrasi dengan menggunakan membran dan proses pertukaran ion.

Proses distilasi dibagi dalam tiga bagian yaitu: multi stage flash distillation, multiple effect distillation dan vapor compression distillation, sedangkan proses membran dibagi menjadi dua yaitu: Reverse osmosis (Osmosa Balik) dan Electrodialysis

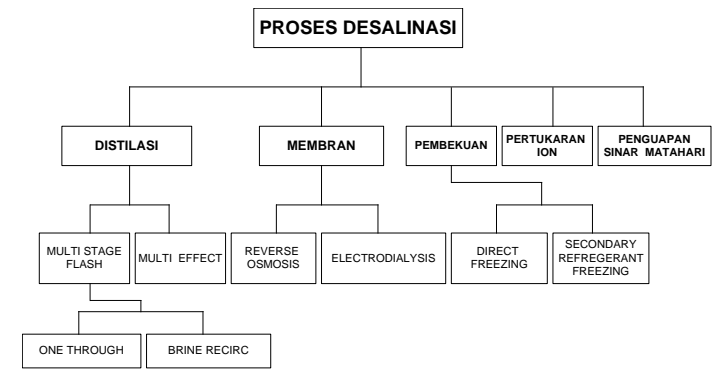

Gambar 1 : Penggolongan Proses Desalinasi

Desalinasi untuk daerah dengan energi berlebih banyak menerapkan proses distilasi seperti pemanfaatan panas buang. Untuk desalinasi dengan kapasitas besar dengan waktu singkat biasa dipakai proses osmosa balik. Berdasarkan data dari Worldwide Desalting Plants Inventory Reports desalinasi yang banyak digunakan saat ini adalah proses distilasi dan proses osmosis balik seperti terlihat pada Tabel 1.

Tabel 1: Jenis proses \& kapasitas desalinasi air asin

\begin{tabular}{|l|r|r|}
\hline \multicolumn{1}{|c|}{ Jenis Proses } & \multicolumn{1}{c|}{$\begin{array}{c}\text { Kapasitas } \\
\left(\mathbf{m}^{3} / \text { day }\right)\end{array}$} & \multicolumn{1}{c|}{$(\%)$} \\
\hline Distilasi & 11.084 .908 & 59,2 \\
(MSF+ME+VC) & & \\
Osmosis Balik & 6.109 .244 & 32,7 \\
Elektrodialisa & 1.070 .005 & 5,7 \\
Lain-lain & 446.110 & 2,4 \\
\hline Total & 18.710 .267 & 100,0 \\
\hline
\end{tabular}

Sumber : "Worldwide Desalting Plants Inventory Reports" yang diterbitkan oleh International Desalination Assosiation (IDA); Mei 1994,

\subsection{Sistem Distilasi}

Pada proses desalinasi dengan sistem distilasi, jumlah air asin sebagai air umpan sebanyak 10 kali dari air tawar yang dihasilkan. Media pemanas dapat menggunakan steam dari boiler atau sumber lainnya. Apabila menggunakan media pemanas berupa steam akan memerlukan jumlah steam pemanas $1 / 6$ dari air yang dihasilkan. Perbandingan jumlah produksi air tawar terhadap jumlah panas steam yang diperlukan disebut Performance Ratio atau Gained Output Ratio (GOR). Rancangan biasanya memakai performance ratio 6 sampai 8 .

Kelemahan sistem distilasisi ini adalah timbulnya kerak dan karat pada tube penukar panas evaporator, dengan demikian efisiensi panas menurun dan produksi air tawar akan berkurang. Dalam kondisi semacam ini proses desalinasi harus diberhentikan untuk pembersihan tube dari kerak dan karat dengan menggunakan larutan asam.

\subsection{Desalinasi dengan Membran Sistem Osmosa Balik}

\subsubsection{Membran Osmosa Balik}

Membran sebagai alat pengolahan air dibagi menjadi tiga jenis, yaitu membran air tawar, membran air payau dan membran air laut. Masing masing jenis membran tersebut mempunyai karakteristik yang berbeda, baik operasionalnya yang ditentukan dengan tekanan operasi maupun kemampuan dalam menahan partikel garam. Membran air tawar mampu mengolah air dengan kandungan TDS sampai 500 ppm dengan tekanan operasi sampai 5 $\mathrm{kg} / \mathrm{cm}^{2}$, membran air payau mampu mengolah air dengan kandungan TDS sampai 12.000 ppm dengan tekanan operasi sampai $10 \mathrm{~kg} / \mathrm{cm}^{2}$ dan membran air laut mampu mengolah air dengan kandungan TDS sampai 40.000 ppm dengan tekanan operasi sampai $50 \mathrm{~kg} / \mathrm{cm}^{2}$. Salah satu contoh bentuk membran osmosa balik dapat seperti pada Gambar 2 dan Gambar 3.

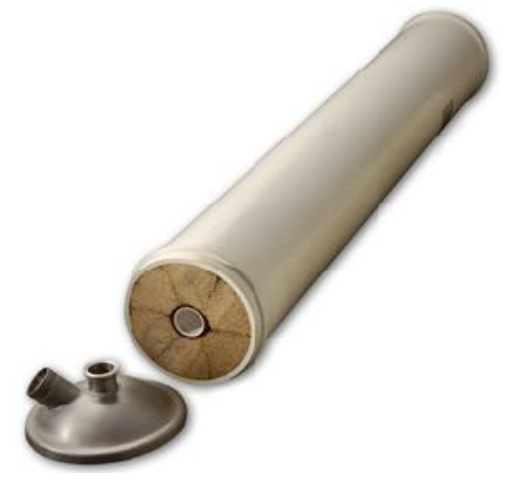

Gambar 2 : Modul Membran

Kapasitas membran ditentukan oleh luas permukaan modul membran, yaitu dengan variabel dimensi membran (diameter dan panjang) maupun jumlah modul membran yang 
digunakan dengan penyusunan seri, paralel maupun kombinasi seri paralel.

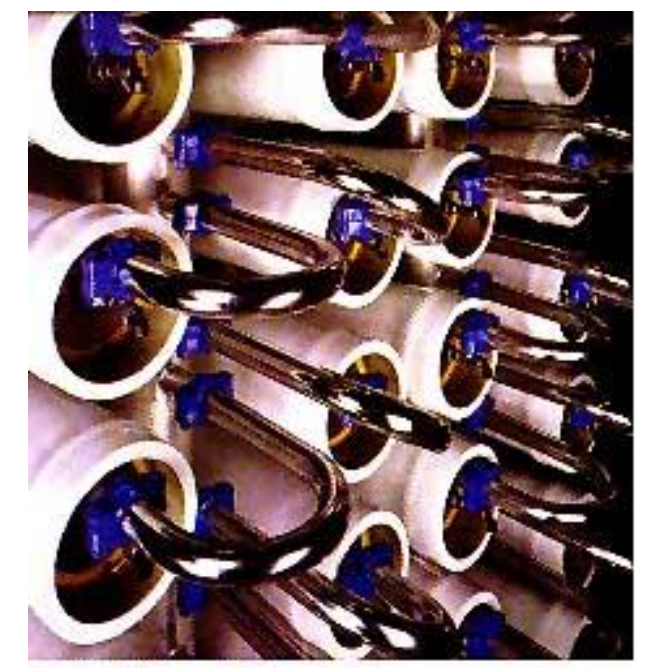

Gambar 3 : Susunan beberapa modul membrane dengan kombinasi seri paralel.

\subsubsection{Prinsip Dasar Osmosa Balik}

Prinsip dasar pengolahan air payau atau asin menggunakan membran sistem osmosa balik secara sederhana dapat diilustrasikan seperti pada Gambar 4.

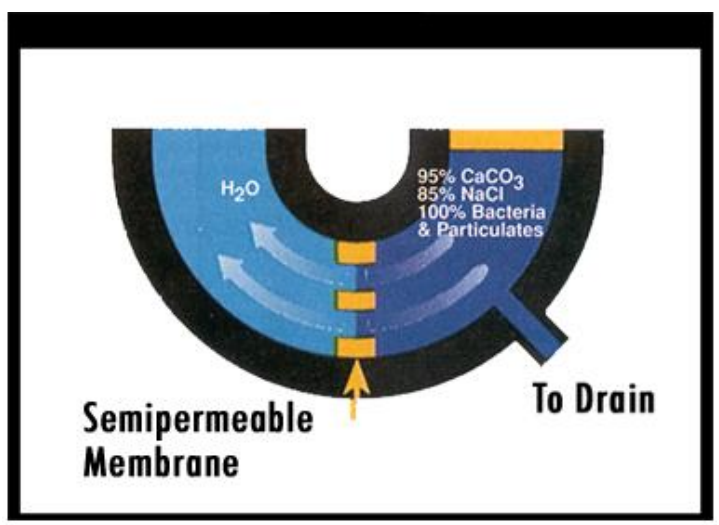

Gambar 4 : Prinsip dasar pengolahan air asin dengan teknologi membran

Apabila dua buah larutan dengan konsentrasi encer dan konsentrasi pekat dipisahkan oleh membran semi permeabel, maka larutan dengan konsentrasi yang encer akan terdifusi melalui membran semi permeabel tersebut dan masuk ke dalam larutan yang pekat sampai terjadi kesetimbangan konsentrasi. Fenomena tersebut disebut proses osmosis. Prinsip dasar proses osmosa dan proses osmosa balik tersebut ditunjukkan seperti pada Gambar 5.
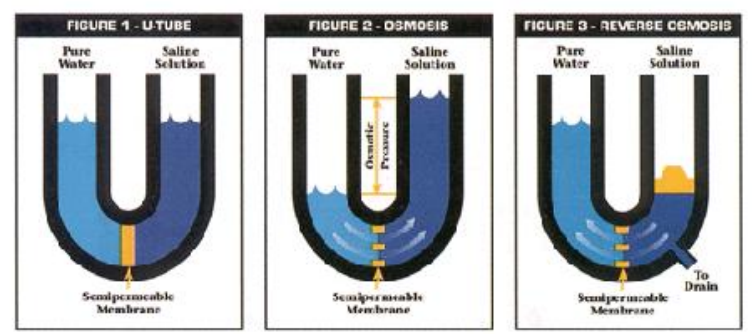

Gambar 5 : Proses Osmosis dan Osmosis Balik

Air tawar yang disebut sebagai larutan dengan konsentrasi encer dan air payau yang disebut dengan larutan dengan konsentrasi pekat dipisahkan dengan membran semi permeabel, maka air tawar akan terdifusi ke dalam air asin melalui membran semi permeabel tersebut, sehingga terjadi kesetimbangan.

Daya yang menyebabkan terjadinya difusi air tawar ke dalam air asin melalui membran semi permeabel dinamakan tekanan osmosis. Tekanan osmosis dipengaruhi karakteristik jenis membran, temperatur air, dan konsentarsi garam (salinitas) serta senyawa lain yang terlarut dalam air (TDS). Air payau mengandung TDS \pm 12.000 pada suhu $25^{\circ} \mathrm{C}$ mempunyai tekanan osmotik normal $\pm 6,9$ $\mathrm{kg} / \mathrm{cm}^{2}$, air laut yang mengandung TDS \pm 35.000 ppm pada suhu $25^{\circ} \mathrm{C}$ mempunyai tekanan osmotik normal $\pm 26,7 \mathrm{~kg} / \mathrm{cm}^{2}$, dan untuk air laut di daerah timur tengah atau laut Merah yang mengandung TDS $\pm 42,000 \mathrm{ppm}$, pada suhu $30^{\circ} \mathrm{C}$, tekanan osmosis $\pm 32,7 \mathrm{~kg} / \mathrm{m}^{2}$.

Dalam sistem osmosis tersebut, apabila diberikan tekanan yang lebih besar dari tekanan osmosisnya, maka aliran air tawar akan berbalik yakni dari air asin ke air tawar melalui membran semi permeabel, sedangkan garamnya tertahan di dalam larutan garammya sehingga menjadi lebih pekat. Proses tersebut dikenal dengan proses Reverse Osmosis (osmosa balik).

\subsubsection{Desalinasi Sistem Osmosa Balik}

Efisiensi proses desalinasi air payau dengan sistem osmosa balik cukup tinggi, mencapai 99,5 \%. Dalam proses osmosa balik ini (Gambar 6), air baku yaitu air payau dipompa dengan tekanan tinggi melampaui tekanan osmosisnya ke dalam suatu modul membran osmosa balik yang mempunyai dua buah pipa keluaran, yakni pipa keluaran untuk air tawar yang dihasilkan (product) dan pipa keluaran untuk air garam yang telah dipekatkan (reject/drain). 


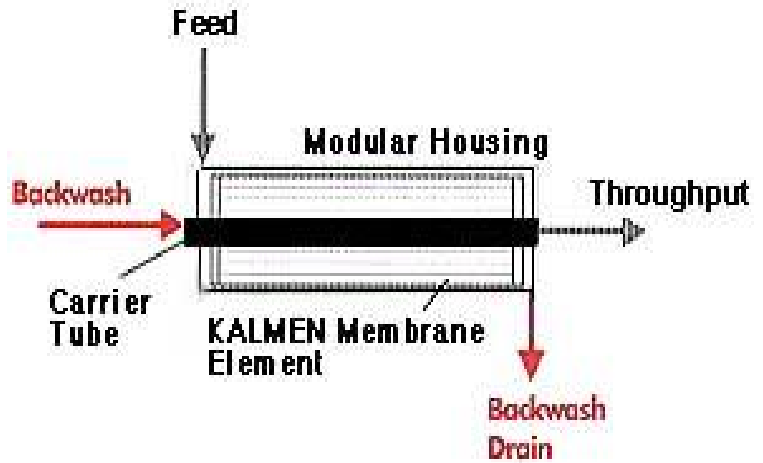

Gambar 6 : Skema desalinasi membran sistem osmosa balik

Dalam proses ini partikel yang molekulnya lebih besar dari pada molekul air, seperti molekul garam dan lainnya, akan terpisah dan akan ikut ke dalam air buangan, sehingga untuk menjaga membran dari kebuntuan, air yang akan masuk ke dalam membran osmosa balik harus memenuhi persyaratan tertentu, misalnya kekeruhan rendah, kadar besi dan mangan dibawah $0,1 \mathrm{mg} / \mathrm{l}$ dan $\mathrm{pH}$ netral. Parameter tersebut harus selalu dikontrol agar tidak terjadi pengerakan kalsium karbonat dan lainnya.

\section{PROSES PENGOLAHAN}

Instalasi pengolahan air payau dengan menggunakan sistem osmosa balik ini sangat dipengaruhi oleh kualitas air baku yang akan diolah, apabila air baku tidak memenuhi persyaratan sebagai air baku osmosa balik seperti Tabel 2, maka Instalasi Pengolahan Air harus dilengkapi dengan unit pengolahan awal (Pretreatment) dan setelah air baku memenuhi persyaratan dilanjutkan pada unit pengolahan lanjutan (Treatment), yaitu unit osmosa balik. Flow diagram proses pengolahan air payau dengan menggunakan sistem osmosa balik dapat dilihat pada Gambar 7.

Tabel 2. Standar Kualitas air baku untuk air umpan unit reverse osmosis

\begin{tabular}{|c|l|c|c|}
\hline No & Parameter & Satuan & $\begin{array}{c}\text { Air baku } \\
\text { (max) }\end{array}$ \\
\hline 1 & Warna & Pt. Co Scale & 100 \\
\hline 2 & Bau & - & Relatif \\
\hline 3 & Kekeruhan & $\mathrm{NTU}$ & 20 \\
\hline 4 & Besi & $\mathrm{mg} /$ liter & 2,0 \\
\hline 5 & Mangan & $\mathrm{mg} /$ liter & 1,3 \\
\hline 6 & Khlorida & $\mathrm{mg} /$ /iter & 4.000 \\
\hline 7 & Bahan Organik & $\mathrm{mg} /$ liter & 40 \\
\hline 8 & TDS & $\mathrm{mg} /$ liter & 12.000 \\
\hline
\end{tabular}

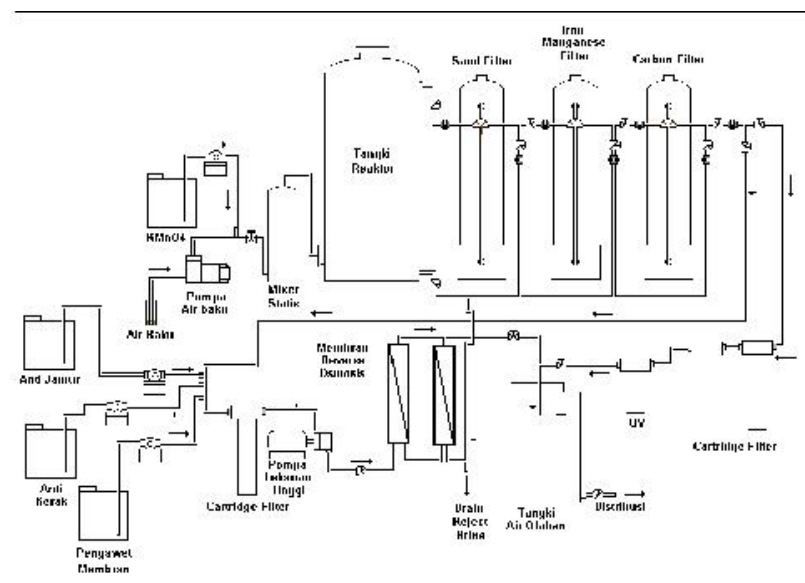

Gambar 7 :Diagram Alir Sistem Pengolah Air Payau.

\subsection{Pengolahan Awal}

Air baku (air payau), terutama yang dekat dengan pantai pada umumnya masih mengandung partikel padatan tersuspensi, mineral, plankton dan lainnya, sehingga diperlukan pengolahan awal sebelum diproses di dalam unit osmosa balik.

Fungsi pengolahan awal adalah untuk memenuhi standar kualitas air baku yang akan diolah pada unit osmosa balik (Tabel-2). Berdasarkan hasil analisa air baku, diperlukan pengolahan awal atau yang disebut dengan pretreatment terdiri dari beberapa unit proses, yaitu oksidasi dan filtrasi. Proses oksidasi menggunakan bahan oksidator $\mathrm{KMnO}_{4}$ sedangkan proses filtrasi menggunakan filter pasir cepat, filter manganese zeolit, filter karbon aktif dan cartridge filter ukuran $0,5 \mu \mathrm{m}$. Peralatan pengolahan awal dilengkapi dengan pompa air baku dengan tekanan operasi 4-5 Bar, pompa dosing dengan tekanan operasi 7 Bar lengkap dengan tangki kimia, tangki reaktor.

Untuk mendapatkan air minum (tawar) 10.000 liter/hari, maka kapasitas total unit sistem pengolahan awal dierlukan air baku tiga kali lipat kapasitas unit pengolahan lanjutan, yaitu sebesar \pm 30.000 liter per hari.

\subsubsection{Proses Oksidasi}

Fungsi oksidasi dengan $\mathrm{KMnO}_{4}$ adalah untuk menangkap kelebihan besi dan mangan atau logam-logam valensi dua lainnya. Selain itu penambahan $\mathrm{KMnO}_{4}$ juga berfungsi sebagai bahan regenerasi media filter manganese zeolit (greensand).

Pembubuhan larutan $\mathrm{KMnO}_{4}$ dilakukan dengan menggunakan pompa dosing kapasitas maksimun sekitar 4,7 liter per jam. Laju injeksi dapat diatur dengan cara mengatur jumlah stroke yang ada pada pompa dosing sesuai dengan 
konsentrasi yang diinginkan. Konsentrasi $\mathrm{KMnO}_{4}$ yang masuk ke static mixer dan tangki reaktor diatur kira-kira 0,3 ppm. Diagram pembubuhan $\mathrm{KMnO}_{4}$ dapat dilihat seperti pada Gambar 8 .

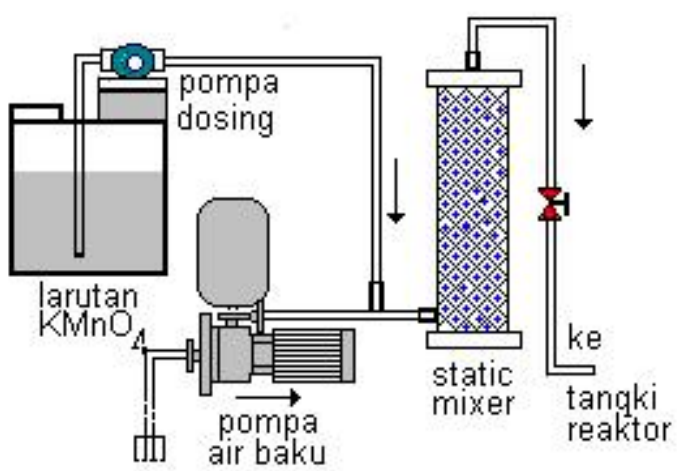

Gambar 8 : Skema injeksi larutan $\mathrm{KMnO}_{4}$

Pencampuran larutan $\mathrm{KMnO}_{4}$ dilakukan di satic mixer selanjutnya proses oksidasi dan sedimentasi dilakukan dalam tangki reaktor

\subsubsection{Filter Pasir Cepat}

Padatan yang ada di dalam air serta oksida besi dan mangan yang terbentuk di dalam tangki reaktor akan tertahan pada filter pasir cepat. Media filter pasir cepat terdiri dari batu kerikil kasar, kerikil halus, pasir silika kasar dan pasir silika halus, dengan susunan dari bawah ke atas adalah sebagai berikut :

- Kerikil kasar $=10 \mathrm{Cm}$

- Kerikil halus $=10$

- Pasir silika kasar

$=30$

$\mathrm{Cm}$

- Pasir silika halus

$=50$

$\mathrm{Cm}$

\subsubsection{Filter Mangan Zeolit}

Penghilangan zat besi atau mangan yang belum teroksidasi oleh $\mathrm{KmnO}_{4}$ dilakukan di filter mangan zeolit. Mangan Zeolit berfungsi sebagai katalis dan pada waktu yang bersamaan besi dan mangan yang ada dalam air teroksidasi menjadi bentuk ferri-oksida dan mangandioksida yang tak larut dalam air.

Reaksinya adalah sebagai berikut :

$$
\begin{gathered}
\mathrm{K}_{2} \mathrm{Z} \cdot \mathrm{MnO} \cdot \mathrm{Mn}_{2} \mathrm{O}_{7}+4 \mathrm{Fe}\left(\mathrm{HCO}_{3}\right)_{2}==>\mathrm{K}_{2} \mathrm{Z}+ \\
3 \mathrm{MnO}_{2}+2 \mathrm{Fe}_{2} \mathrm{O}_{3}+8 \mathrm{CO}_{2}+4 \mathrm{H}_{2} \mathrm{O} \\
\mathrm{K}_{2} \mathrm{Z} \cdot \mathrm{MnO} \cdot \mathrm{Mn}_{2} \mathrm{O}_{7}+2 \mathrm{Mn}\left(\mathrm{HCO}_{3}\right)_{2}==>\mathrm{K}_{2} \mathrm{Z}+ \\
5 \mathrm{MnO}_{2}+4 \mathrm{CO}_{2}+2 \mathrm{H}_{2} \mathrm{O}
\end{gathered}
$$

Reaksi penghilangan besi dan mangan dengan mangan zeoilte tidak sama dengan proses pertukaran ion, tetapi merupakan reaksi

dari $\mathrm{Fe}^{2+}$ dan $\mathrm{Mn}^{2+}$ dengan oksida mangan tinggi (higher mangan oxide). Filtrat yang terjadi mengandung ferri-oksida dan mangan-dioksida yang tak larut dalam air dan dapat dipisahkan dengan pengendapan dan penyaringan. Selama proses berlangsung kemampunan reaksinya makin lama makin berkurang dan akhirnya menjadi jenuh. Untuk regenerasinya dapat dilakukan dengan menambahkan larutan Kalium permanganat ke dalam mangan zeolite yang telah jenuh tersebut sehingga akan terbentuk lagi mangan zeolite $\left(\mathrm{K}_{2} \mathrm{Z} . \mathrm{MnO} \cdot \mathrm{Mn}_{2} \mathrm{O}_{7}\right)$.

Media terdiri dari batu kerikil kasar, kerikil halus, pasir silika kasar, pasir silika halus dan mangan zeolit. Susunan media dari bawah ke atas adalah sebagai berikut :

- Kerikil kasar

- Kerikil halus

- Pasir silika kasar

- Pasir silika halus

- Manganese Zeolit

$\begin{array}{ll}=10 & \mathrm{Cm} \\ =10 & \mathrm{Cm} \\ =10 & \mathrm{Cm} \\ =20 & \mathrm{Cm} \\ =50 & \mathrm{Cm}\end{array}$

\subsubsection{Filter Karbon aktif}

Pada filter karbon aktif ini terjadi proses adsorpsi, yaitu proses penyerapan zat-zat yang akan dihilangkan oleh permukaan karbon aktif. Apabila seluruh permukaan karbon aktif sudah jenuh, atau sudah tidak mampu lagi menyerap maka proses penyerapan akan berhenti, dan pada saat ini karbon aktif harus diganti dengan karbon aktif yang baru. Saringan karbon aktif berfungsi untuk menghilangkan polutan mikro misalnya zat organik, deterjen, bau, senyawa phenol serta untuk menyerap logam berat dan lain-lain.

Susunan media dari bawah ke atas adalah sebagai berikut :

- Kerikil kasar

- Kerikil halus

- Pasir silika kasar

- Pasir silika halus

- Karbon aktif

$\begin{array}{lll}= & 10 & \mathrm{Cm} \\ = & 10 & \mathrm{Cm} \\ = & 10 & \mathrm{Cm} \\ = & 10 & \mathrm{Cm} \\ = & 60 \mathrm{Cm}\end{array}$

\subsubsection{Cartridge Filter}

Untuk penyempurnaan pengolahan awal, proses dilengkapi dengan cartridge filter dengan ukuran $0,5 \mu \mathrm{m}$, sehingga secara keseluruhan produk air dari unit pengolahan pendahuluan ini diharapkan mempunyai kualitas yang dipersyaratkan seperti tabel-2 yaitu, kekeruhan < $5 \mathrm{NTU}, \mathrm{Fe}, \mathrm{Mn}<0,1 \mathrm{ppm}$ dan Chlorida juga < $0,01 \mathrm{ppm}$. Air hasil penyaringan melalui cartridge filter ini ini aman untuk unit reverse osmosis. 
Secara keseluruhan unit pengolahan pendahuluan di atas belum dapat menghilangkan kadar garamnya, sehingga diperlukan pengolahan lanjutan untuk penghilangan garamnya (desalinasi)

\subsection{Pengolahan Lanjutan}

Pada tahapan pengolahan lanjutan ini dilakukan proses penyaringan dengan menggunakan membran. Prinsip proses ini adalah pemisahan air dari pengotornya didasarkan pada proses penyaringan dengan skala molekul. Untuk menghasilkan air tawar, air payau yang telah memenuhi persyaratan sebagai air baku dipompa dengan tekanan tinggi ke dalam suatu modul membran osmosa balik.

Efisiensi penghilangan garam dengan proses reverse osmosis ini mencapai 99,5\%. Modul membran osmosa balik mempunyai dua buah pipa keluaran, yakni pipa keluaran untuk air tawar sebagai produk dan pipa keluaran untuk air garam yang telah dipekatkan sebagai buangan. Di dalam membran Osmosis Balik terjadi proses penyaringan dengan skala molekul, yaitu partike yang molekulnya lebih besar dari pada molekul air, misalnya molekul garam dan lainnya, akan terpisah dan akan ikut ke dalam air buangan. Oleh karena itu air yang akan masuk ke dalam membran osmosis balik harus mempunyai persyaratan tertentu, misalnya kekeruhan harus nol, kadar besi harus $<0,1 \mathrm{mg} / \mathrm{l}, \mathrm{pH}$ harus dikontrol agar tidak terjadi pengerakan kalsium karbonat dan lainnya.

Dalam pengoperasian penyaringan skala molekul ini diinjeksi 3 jenis bahan kimia, yaitu anti scalant (anti pengerakan), anti biofouling (anti penyumbatan karena unsur biologis) dan bahan pengawet yang berfungsi untuk mengawetkan membran yang berupa Thin Composite Film, bahan kimia tersebut tersaring dan akan keluar bersama dengan air buangan.

Air hasil olahan mempunyai kualitas sebagai air siap minum, yaitu memenuhi standar kualitas air minum yang disyaratkan oleh WHO maupun Departemen Kesehatan RI. Kandungan jumlah padatan terlarut umumnya lebih kecil dari 150 ppm. (Tabel 3).

\section{PERALATAN IPA SISTEM OSMOSA BALIK}

\subsection{Peralatan Utama}

Peralatan utama dalam sistem pengolahan awal didisain sesuai dengan kualitas air baku yang terdiri dari 5 unit pemroses, yaitu unit pencampur statis (static mixer), unit tangki reaktor , filter pasir cepat, filter mangan zeolit dan filter karbon aktif dalam kondisi tertentu diperlukan tambahan clarifier. Sedangkan perangkat utama pengolahan lanjutan adalah membran osmosa balik

\subsection{Perangkat Penunjang}

Perangkat penunjang dalam sistem pengolahan pendahuluan ini dipasang untuk mendukung operasi unit pretreatment yang terdiri dari 4 bagian, yaitu pompa air baku, pompa dosing, tangki kimia dan perpipaan serta kelengkapannya.

\subsection{Kapasitas Pengolahan Pendahuluan}

Spesifikasi dari setiap unit pemroses dalam sistem pengolahan pendahuluan didisain untuk mengolah air baku dengan kapasitas \pm 3 kali lipat kapasitas sistem osmosa balik, dimana sepertiganya akan diolah menjadi air tawar sisanya sebagai reject untuk membuang garamnya.

\subsection{Kapasitas Pengolahan Lanjutan}

Unit pengolah lanjutan merupakan peralatan utama dalam mengolah air payau. Sistem osmosa balik yang diterapkan mempunyai kemampuan mengolah air baku 30.000 liter/hari dan mampu untuk memproduksi air hasil olahan (produk) 10.000 liter/hari dan sisanya sebagai buangan (asin). Untuk mendukung kerja alat pengolah air payau sistem reverse osmosis ini dilengkapi dengan beberapa alat ukur seperti: pengukur tekanan operasi (pressure meter), pengukur laju alir (flow meter) dan pengukur kandungan garam serta rangkaian elektrik untuk otomatisasi operasi sistem.

\section{PENUTUP}

Kepulauan seribu terdiri dari 111 seribu buah pulau-pulau kecil merupakan salah satu wilayah Jakarta Utara, Propinsi DKI Jakarta dengan jumlah penduduk sekitar 18.000 jiwa, namun pulau yang diperuntukkan sebagai daerah pemukiman ada sebelas buah pulau, yaitu: $P$. Untung Jawa, P. Tidung Besar, P. Lancang Besar, P. Panggang, P. Pramuka, P. Kelapa I, P. Kelapa II, P. Harapan, P. Sebira. P. Payung dan P. Pari. P. Panggang dan P. Kelapa I berpenduduk cukup padat.

Air tanah dangkal yang saat ini dimanfaatkan oleh masyarakat setempat hanya tersedia pada saat musim hujan dan pada saat kemarau panjang air tawar akan habis, penampungan air hujan atau yang disebut $\mathrm{PAH}$ yang dimiliki oleh masyarakat kuantitasnya sangat terbatas, sehingga masyarakat kepulauan seribu mendatangkan dari daerah lain, seperti 
Tanjung Priok, Tangerang dan pulau-pulau lain yang masih ada sumber air tawar.

Instalasi pengolahan air asin atau payau sistem osmosa balik menjadi salah satu alternatif untuk memenuhi kebutuhan air minum, yang dibagi menjadi dua bagian utama, yaitu unit pengolahan pendahuluan dan unit pengolahan lanjutan.

Manfaat secara langsung penerapan teknologi pengolahan air payau sistem osmosa balik ini adalah masyarakat setempat dapat memperoleh air minum yang sehat dan memenuhi persyaratan sebagai air minum dengan harga yang terjangkau dan manfaat secara tidak langsung adalah memberi gambaran unit percontohan penerapan teknologi tinggi yang dikemas sangat sederhana akan dapat dan mudah dioperasikan dan dapat diterapkan pada daerah lain. Manfaat umum lain adalah peningkatan taraf kehidupan masyarakat, karena dengan mengkonsumsi air yang bersih dan sehat berarti masyarakat juga terhindar dari kemungkinan menderita sakit (muntaber, disentri atau thypus) dengan demikian kesejahteraan juga akan meningkat.

\section{DAFTAR PUSTAKA}

1. Arie, H, 1989, Teknologi Pengolah Air Asin Reverse Osmosis dan prospeknya di Indonesia, Proceeding Seminar Teknologi Pengolahan Air, Krakatau Steel, Cilegon.

2. Fair, G.M., Geyer, J.C., AND Okun, D.A., " Element Of Water Supply And Waste Water Disposal ", Second Edition, John Wiley And Sons, New York, 1971

3. Hamer, M. J., "Water And Waste water Technology ", Second Edition, John Wiley And Sons, New York, 1986

4. Nusa, I.D., Arie, H., Nugro, R., dan Haryoto, I., 1996, Studi Kelayakan Teknis dan Ekonomis Unit Pengolah Air Sistem Reverse Osmosis Kapasitas 500 m3/hari Untuk perusahaan minyak lepas pantai, P.T. Paramita Binasarana, Jakarta.

\section{LAMPIRAN}

Tabel 3 : Kualitas air baku dan air hasil olahan.

\begin{tabular}{|c|c|c|c|c|c|}
\hline No. & PARAMETER & SATUAN & $\begin{array}{l}\text { Standar air } \\
\text { bersih }\end{array}$ & Air Baku & Air Olahan \\
\hline 1 & Warna & Skala TCU & 50 & 60 & 10 \\
\hline 2 & Bau & - & Tak berbau & Tak berbau & Tak berbau \\
\hline 3 & Rasa & - & Tak berasa & $A \sin$ & Tak berasa \\
\hline 4 & Kekeruhan & NTU & 25 & 1,18 & 0,341 \\
\hline 5 & Suhu & ${ }^{\circ} \mathrm{C}$ & $\begin{array}{c}\text { Suhu udara } \\
+3\end{array}$ & 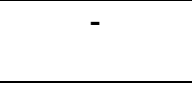 & - \\
\hline 6 & Jumlah zat padat terlarut (TDS) & $\mathrm{mg} / \mathrm{l}$ & 1500 & 3000 & 140,0 \\
\hline 7 & Zat organik (KMNO4) & $\mathrm{mg} / \mathrm{l}$ & 10 & 59 & 3,48 \\
\hline 8 & Derajad keasaman $(\mathrm{pH})$ & - & $6,5-9,0$ & 7,7 & 6,7 \\
\hline 9 & Kesadahan jumlah (CaCO3) & $\mathrm{mg} / \mathrm{l}$ & 500 & 428,75 & 32,31 \\
\hline 10 & Besi $(\mathrm{Fe})$ & $\mathrm{mg} / \mathrm{l}$ & 1,0 & 0,2977 & 0,0903 \\
\hline 11 & Mangan (Mn) & $\mathrm{mg} / \mathrm{l}$ & 0,5 & 0,1192 & 0,0321 \\
\hline 12 & Sulfat (SO4) & $\mathrm{mg} / \mathrm{l}$ & 400 & 6 & 2 \\
\hline 13 & Nitrit $(\mathrm{sbg}-\mathrm{N})$ & $\mathrm{mg} / \mathrm{l}$ & 1,0 & 0,6978 & 0,0115 \\
\hline 14 & Klorida & $\mathrm{mg} / \mathrm{l}$ & 600 & 2836,45 & 61,06 \\
\hline 15 & Seng $(Z n)$ & $\mathrm{mg} / \mathrm{l}$ & 5,0 & - & - \\
\hline 16 & Kromium (Cr) & $\mathrm{mg} / \mathrm{l}$ & 0,05 & - & - \\
\hline 17 & Timbal (Pb) & $\mathrm{mg} / \mathrm{l}$ & 0,05 & - & - \\
\hline 18 & Sisa Chlor & $\mathrm{mg} / \mathrm{l}$ & - & - & \\
\hline
\end{tabular}

PDAM, Agustus 2002 